\title{
The sounds of "water" in German and Russian phonosemantic pictures of the world
}

\author{
Olga Shestakova ${ }^{1, *}$, Liudmila Yashmanova $^{1}$, and Svetlana Demidova $^{1}$ \\ ${ }^{1}$ Perm National Research Polytechnic University, 614990, 29 Komsomolsky ave., Perm, Russia
}

\begin{abstract}
The correlation of the concepts of the phonosphere, the sound picture of the world, the phonosemantic picture of the world is defined. The sounds of water as an integral part of the sound phonosemantic picture of the world are chosen. A comparative phonosemantic and quantitative analysis of German and Russian verbs nominating the sounds of water is presented. The types of water sounding on the basis of universal phonosemantic typology by S. V. Voronin are revealed. Some quantitative differences of onomotopes of water sounding from acoustic onomatopoeia studied by the author earlier on the materials of the German and Russian languages are noted as a whole. Analysis of this fragment of the phonosemantic picture of the world confirms the conclusion that universal features in onomatopoeia prevail over specific ones.
\end{abstract}

The concept "water" is studied from different points of view on the material of various languages, interpretation of the figurative component of the concept of water in the linguistic picture of the world on the basis of nominative and metaphorical fields of the Russian language [1]; representation of the concept "Wasser" in German artistic picture of the world in the diachronic and synchronic aspects [2]; the content of the concept "water" in the English language [3]; the concept "water" as a binary concept in relation to the concept "fire" in genetically non-cognate English and Tatar languages [4]; conceptualisation of water used by a linguistic personality of a generalized narrator of the heroic epics texts in the English, German and Russian languages [5]; the concept of water in everyday and public discourse [6]. The concept of water in all the studies mentioned above is presented as a fragment of the linguistic picture of the world. According to the $\mathrm{T}$. I. Badmaeva, it is the basic one in the English language [3]. Currently, we have not found any studies of lexical units that nominate water sounding in the phonosemantic aspect.

The semantic group "Liquid" (water, rain, stream, as well as blood, tears, etc.) is a fragment of the phonosemantic sound picture of the world which is understood as a part of the linguistic picture of the world, explicated in a language by the phonic iconicity vocabulary [7-11].

It is necessary to explain here the correlation of the concepts of the phonosphere, the sound picture of the world, the phonosemantic picture of the world. Phonosphere is a kind of sound continuum, represented both at the material spatial and abstract levels, filled with

* Corresponding author: shestakova64@ mail.ru 
different types of biological (often unrealized by man), in technical and cultural-semiotic (realized by man) sound systems [12]. The sound picture of the world is a part of the phonosphere realized by man and explicated in a language; a part of the linguistic picture of the world; a set of ideas about the world sounding reflected in a language; a way of conceptualizing the sound space. The phonosemantic picture of the world is a part of the linguistic picture of the world reflected in a language by means of phonosemantic units and categories. Within the framework of the phonosphere biological (natural) and social (artificial, anthropo- and culturally-oriented) phonospheres are distinguished. Within the framework of biophonosphere it is possible to distinguish:

1) Naturphonosphere - the sounds of nature in a natural phylosophysence (water, air, fire, earth) including phonosphere of precipitation, atmospheric conditions and other meteorological phenomena (rain, snow, movement of air and water, landslides, drifting of ice etc.): German gluck, cluck "sound of fluid motion", rutsch "sound of sliding"; Russ. svistet', vyt' "whistle, wail (of wind)";

2) Phytophonospere - the sounds of plants (the sound of leaves, growth, withering, destruction, breaking, interaction and physical contacts, etc.): German knicks, Russ. krak "the sound of wood breaking";

3) Zoophonosphere - screams (voices) and sounds of animals and birds while moving, eating, interacting: Germ. quak, Russ. kva-kva “croaking”, Germ. sum, Russ. Zhzhzh "insect buzzing";

4) Anthroponoosphere - sounds made by humans (except speech sounds) while moving, travelling, eating, interacting: Germ. ach, Russ. akh, okhat' "sigh", Germ. happs, Russ. Am, kham "the sound of biting, mouth griping", Germ. hatschi, Russ. apchkhi "the sound of sneezing". The sounds of water are an integral part of naturphonosphere.

Despite the fact the sound picture of the world has attracted the attention of many researchers, this part of the sound picture of the world hasn't reached the systematic description yet. This problem is solved partially in separate studies $[12,13,14,15]$.

Naturally that onomatopoeia is the basic means of reflection in a language of the sound picture of the world. At the same time "simplicity" of onomatopes is "seeming simplicity. The meaning of this word is a complex and versatile formation" [16; p.29].

The material of the study included 40 German and Russian verbs denoting the sounds of water movement, 29 German verbs were found in the description of water movement in the Millstatt gorge in the Austrian Alps: blubbern, brodeln, donnern, dröhnen, glucksen, gurgeln, hallen, klatschen, murmeln, nieseln, perlen, plätschern, poltern, prasseln, pritscheln, rauschen, rinnen, rumpeln, säuseln, sausen, schäumen, spritzen, sprudeln, sprühen, strömen, tosen, trommeln, tröpfeln, zischen "seit Jahrtausenden klingt die Millstlättter Schlucht ohne Dirigent und Komponist"'”.

The following methods were used in the study: continuous sampling method, lexicalsemantic, etymological, comparative and descriptive methods, quantitative analysis, as well as the actual phonosemantic methods including the etymological phonosemantic analysis, and phonotype modeling.

The onomatopoeic origin of the majority of language units is confirmed in etymological and explanatory dictionaries $[17,18,19,20]$. It should be noted that the units studied include not only "evident" onomatopoeias, but also the words that have lost connection with acoustic denotation. The phonic iconicity of such words is based on the etymological phonosemantic analysis. For example, the German perlen "leak", "drip" < Germ. Peerle < Fr. Perle "pearl" < Lat. perna "a kind of a sea shellfish" [19], Fr. Perler "peel (barley, rice)", Ital. perlato "purified, polished", Port. Perlavar "purify, clean"; Rus. penit'sya "foam" < Lat. spuma "foam, splashes", Lat. Pumex "pumice" < Germ. bimsen "clean with pumice"; coll. "beat" [18]. 
The involuntary connection between sound and meaning is proved on the material of typologically diverse languages. Phonic iconicity words of different languages are comparable to each other at the phonotype level, that is the phoneme type depending on its acoustic-articulatory characteristics (occlusive, fricative, explosive, voiced, sonorous, etc.). Classification of the phonic iconicity system at the phonotype level is presented in the universal typology of S. V. Voronin [21] where a significant place is occupied by acoustic onomatopes. Acoustic onomatopes are the units reproducing non-articulatory acoustic sounds of external environment by means of phonemes: Germ. blubbern; Rus. bul'kat' "gurgle". On the basis of the universal phonosemantic typology made by S.V. Voronin 12 types of sounds of water have been revealed.

\section{Class A. Instants}

\section{Type 1. Instants}

It refers to "ultra-short" noise or tone which is equally perceived by human ear as an acoustic blow: Germ. Patschen "slap"; peitschen "whip"; toben "rave, bluster"; Russ. bit' "beat"; stuchat' "knock"; kapat' "drip"; tech' "flow”; tochit'sya "sharpen” Germ. Der Regen patscht / peitscht gegen die Scheiben; Rus. Yesli nachinalas' groza, dozhd' stuchal po fanere. [If it was a thanderstorm, the rain poundered the plywood] (S. Dovlatov); Dozhd' kapal beznadyozhno, beznadyozhno revel zavodskoy gudok. [The rain dripped hopelessly, hopelessly the factory whistle roared] (B. A. Pilnyak). The intensity of the sound is expressed by explosive: Germ. /p/, /b/, /t/ and/or by affricate /t $/ /$; Russ. /p/, /b/, /m/, /k/ and/or by affricate $/ \mathrm{t} \mathrm{f} /$.

\section{Class B. Continuants}

\section{Type 2. Tone continuants}

It is a lack of tone accent, that is, tone in its purest form: Germ. nieseln, pieseln "drizzle"; sickern "trickle down, ooze"; Russ. seyat' "saw”, sypat' "strew (of small, frequent rain)"; sochit'sya "ooze, trickle down". Germ. Auch das Wetter und die Gegend waren nicht gerade festtagmäßig, es nieselte leise (H. A. Kruger); Das Wasser sickert nach unten, bis es auf eine Filsbarriere trifft (R. Kilian); Rus. Melkiy dozhd' seyet s utra: vyyti nevozmozhno [A fine rain sows in the morning: it is impossible to get out] (I. S. Turgenev). ... n na mostu cherez ovrag dozhd' syplet sil'neye [And on the bridge over the ravine, the rain falls heavier] (M. Shishkin). The monotonous nature of the sound is expressed by vowels: Germ. /i/, Rus. /e/, /i/, /y/.

\section{Type 3. Pure noise continuants}

It is a lack of acoustic accent blow, i. e. noise in its purest form: Germ. zichen; Russ. shipet' "hiss". Germ. Und es wallet und siedet und brauset und zischt (F. von Schiller); Rus. Voda shipit i penitsya za bortom i bryzzhet vnutr'. [Water hisses and foams over board and splashes inside] (A. I. Kuprin). The noise is expressed by a fricative consonant: Germ. [S], Rus. [S].

\section{Type 4. Tone-noise continuants}

It is noise with elements of tone: Germ. säuseln "rustle (of leaves, petals, etc.)", sausen "noise, whistle (of wind, etc.)", schäumen "foam"; Russ. shelestet', shumet', zvuchat' [rustle, noise, sound]. Germ. Im Frühling säuseln nicht nur die Bäche süsser, die ganze Welt ist von Duft und Glanz beseelt (M. Minder); Immer weiter runter saust das Wasser; $\mathrm{Ob}$ Sommerhitze oder starker Regen hallt (Gästebuch - Rohnspitzler); Rus. 
Sssssssssssssss!... - uslyshal ya i podumal, chto eto melkiy dozhdik shelestit. [Ssssssssssssssss!. - I heard and thought that this small rain rustles] (Y. Koval).; Vot tak vo mne trepeshchet mozg, pokuda dozhd' shumit. [That's how the brain trembles inside me, as long as rain is noisy] (I. A. Brodsky). [That's how the brain trembles inside me, as long as rain is noisy]. Tone nature of sounding is expressed by vowels / diphthongs: Germ. /au/, /au/; Russ. /e/, /u/ and by sonorous consonants: Germ. /1/, /m/; Russ. /1/, /m/. Noise with elements of tone is expressed by fricative consonants: Germ. /s/, / / $/$ Rus. /z/, / $/$.

\section{Type 5. Frequentatives-quasiinstants}

It is a dissonant blow, combining the signs of a "pure" dissonance and a blow; psychoacoustically this is the sound of a "hoarse" impulse, having a tendency to split into two pulses, but still felt as a single impulse (a crackling, scraping sound, etc.): Germ. brodeln "bubble", Rus. krapat', kropit' "drop in small rare drops". Germ. Eines Tages in den Quellen scheinbar ausgedorrter Bäche brodeln neue Lebenswellen (Phenixxenia); Rus. Dozhd nakrapy`vaet, kak by` groza ne sobralas'? [It is drizzling. There may be a storm soon.] (A. N. Ostrovsky). The blow followed by a roar is expressed by an explosive: Germ. /b/,/d/; Rus. /k/, /p/ and a vibrant: Germ /r/; Rus. /r/.

\section{Type 6. Pure frequentatives}

It is a pure dissonance, i.e. a series of blows, shaking: a fractional shaking sound (a rumbling, crackling sound of blows); the trembling sound of movement, rotation (of solids); swirling, murmuring (the trembling sound of turbulent water movement), etc.: Germ. gurgeln "boil up", Rus. burlit` "boil up", burchat' "babble", zhurchat' "purl". Germ. Und der Bach gurgelt lease, viel besser als im Sommer (K. Zimmermann); Rus. Kamni krugly', skol 'zki, kak golova tyulenya, voda burlit. [The stones are round, slippery like the head of the seal, the water is boiling up.] (V.I. Shishkov); Potom on spustilsya v lozhok tam rucheyok zhurchit [Then he went down to a small ravine. A brook is purling there.] (V. Shukshin). The striking nature of a sound is expressed by an explosive: Germ /g/; Rus. /b/, multiple blows are expressed by a vibrant: Germ. /r/; Rus. /r/.

\section{Type 8. Frequentative pure noise quasicontinuants}

It is a pure quasi-blow, where a pure dissonance is followed by a lack of acoustic accent; Germ. rauschen "rustle; splatter"; Rus. shurshat' "rustle", rokotat’ "roar". Germ. Wo der Wildbach rauscht (Volkslied); Rus. Pavel vy`shel na bort, prislushivayas`, kak zatihaet shurshanie vody' i tumana [Pavel went up to the deck listening how the rustling of water and fog was calming down] (V. Rasputin); Nikakogo zvuka ne dohodilo do goroda, tol 'ko s gor skvozilo rokotanie dalekoj by`stroj reki [It was absolutely quiet in the garden, there was only a gentle roaring from a distant, fast river in the mountains] (A. P. Platonov). The vibrant expresses a pure dissonance: Germ. /r/; Rus. /r/, a lack of acoustic accent is expressed by a deaf fricative: Germ $/ \mathrm{J} /$, Rus. $/ \mathrm{J} /$.

\section{Hyperclass AB. Instants-continuants}

\section{Type 10. Tone "post-blow" instants-continuants}

They express a blow followed by lack of tonal accent. Germ donnern "thunder", poltern "fall with noise," bullern "boil up"; Rus. lit`sya "flow", penit`sya "foam", raspy`lyat`sya "spray" Germ. Regen peitscht das Land, die Buche donnern ihrem Ziel entgegen! (H. K. Costa); Ein scharfer Schlaf, ein durchdringende «ziit, tiit» erklingt unten am Bache, ein Ruf, wie geschaffen, das Poltern der Flut und das Brausen des Windes zu (H. Loans); Rus. Ruchej prosto i pokojno l'yotsya v shage ot tebya, hochesh` - pej, a ne hochesh` kak 
hochesh ' A brook is flowing quietly nearby. You may drink from it or not. As you like] (Vladimir Makanin); Ya sel v kreslo, nablyudaya, kak penitsya sbegayushchij v okean rucheyok, i v koncze konczov zasnul [I sat down in an arm-chair watching as a tiny brook flowing into the ocean was foaming and finally I fell asleep] (W. Gubarev). An explosive expresses the blow nature of the sound: Germ. /p/, /b/, /d/; Rus. /p/, a sonorous reflects a lack of tone accent: Germ. /1/, /n/; Rus. /1/.

\section{Type 11. Pure noise "post-blow" instants-continuants}

It expresses a blow followed by a pure lack of acoustic accent: Germ. tosen "rage, make noise"; Rus. bushevat' "rage" "flow violently, swiftly, with destructive force; rave (about natural elements, etc.)" Germ. Jedes andere Wort verschluckte das Tosen des Wassers oder der Wind (Ransmayer); Rus. Kogda more bushuet, u menya ot straha azh razdiraet vse iznutri [When the sea is raging, I am overwhelmed with fear] (V. Burlak). An explosive expresses a blow nature of the sound: Germ. /s/; Rus. /J/.

\section{Type 12. Pure noise "pretonic" instants-continuants}

It expresses a blow preceded by a lack of acoustic accent: Germ. blubbern, gluckern, glucksen "gurgle"; klatschen "knock"; plätschern "babble"; hallen "sound, boom"; wallen "boil up", fließen "flow, pour"; schlagen "spout"; Rus. klokotat' "babble", hlestat "beat down", hly`stat "whip", hlyupat` "squelch", hloby`stat` "strike", hly`nut` "gush", poloskat'sya "paddle", pleskat`sya "swash". Germ. Der "Fluss" blubbert wie ein begradigter Bach im scheinbar viel zu großen Kanalbett dem ungleich mehr Wasser führenden "Kanal" entgegen (Wiener Zeitung). Der Bach plätschert über die Steine (Duden); Wellen, die ans Ufer schlagen und dabei die Steine murmeln lassen (Moewenschrei); Rus. Voda klokochet $\mathrm{v}$ ee vetvyah, volny' $\mathrm{v}$ pene pereskakivayut cherez stvol, vozle kotorogo kuvy`rkaetsya i tolchetsya razny $\mathrm{j}$ plavuchij musor [The water is babbling in its branches, the foamy waves are skipping over its trunk and various floating garbage is jumbling over it] (A. Ivanov); Voda tyazhyolaya, pleshhetsya, srazu zamerzaet na stupenyax [The water is heavy, it is swashing and almost instantly freezing on the steps] (I. Grekova). The blow nature of the sound is expressed by an explosive and / or an affricate: Germ. /b/, /g/, /k/, /p/, /t/; Rus. /k/, $/ \mathrm{p} /, / \mathrm{b} /$, water movement is expressed by a sonorous: Germ. /1/; Rus. /1/, a lack of acoustic blow is expressed by a fricative: Germ. /f/, /h/; Rus. /h/, / $/$.

\section{Hyperclass BAB. Frequentatives - Quasi-instants -Continuants}

\section{Type 16. Tone "post-blow" quasi-instants-continuants}

It is a quasi-blow followed by a lack of tone accent: Germ. dröhnen "rattle"; trommeln "drum"; rinnen "flow, stream"; rumpeln "rumble"; murmeln "babble"; perlen "flow, drip"; Rus. gremet` "thunder", gromy'hat` "pour heavily", barabanit` "patter", tarabanit’ "beat on", brenchat’ "jingle" Germ. Die Bäche rinnen nach den Strömen zu, als wären sie von Tränen angeschwellt (Wulf E. Bley); Bäche murmeln in träumenden Ufern (C. Hauptmann). Wenn Regengüsse auf ein Blechdach trommeln, dann kann das unter Umständen ganz schön auf die Nerven gehen (http://www.augsburger-allgemeine.de/). An den Blättern einiger Pflanzen perlt Wasser wunderbar ab (www.tagesspiegel.de); Rus. I vezde ruch `i gremyat, kak dobry`e zherebcy rzhut [Streams are thundering everywhere giving a neighing sound] (B. V. Shergin); Gromy 'haet lavina dozhdya, kak by` predvaryaya grohot vodopada [The rain is heavily pouring as if preceding the waterfall roar] (L. Ozerov). Kogda stuchit za oknom dozhd', tarabanit po verande, i tumanyatsya nepogodoj sizy`e gory', na pamyat prihodyat dorogi [When the rain is knocking on the window, beating on the terrace and the mist is covering blue-grey mountains all of a sudden you may recall the roads] (K. 
Seraphim). The quasi-blow is expressed by the vibrants: Germ. /r/; Rus. /r/, a lack of tone accent is expressed by a sonorous: Germ. $/ \mathrm{m} /, / \mathrm{n} / ;$ Rus. $/ \mathrm{m} /, / \mathrm{n} /$.

\section{Type 17. Pure noise "post-blow" quasi-constants-continuants}

They express a quasi-blow followed by a pure lack of acoustic accent: Germ. prasseln "fall with noise"; pritscheln "babble, splash"; spritzen "sprinkle"; "drizzle (about the rain)", sprühen "spray"; sprudeln "spout (about the spring)"; strömen "flow (about water)"; tröpfeln "drip"; brausen "rush with a noise "; Rus. bry`zgat' "spray", pry`skat',"drizzle", grohotat "thunder", struit'sya "stream". Germ. Das Prasseln des Regens wurde von einem dumpfen Geräusch übertönt (N. Wickbold). Regen pritschelt es auch mal kräftig daneben (Photovoltaikforum). Regen tröpfelte von den verwelkenden Blättern der Bäume (Duden); Das Wasser des Farnsbrunn am «Weg 6» im Gemeindewald, angrenzend an den Fechenbacher Wald, sprudelt wieder oberirdisch (Main-echo); Ein kleiner Gebirgsbach braust jetzt neben der Strecke gischtend zwischen gewaltigen Blöcken dahin (H. Wendel); Rus. Naprimer, spuskalsya ya k Alma-Atinke, ostanavlivalsya na kamnyah, stoyal i smotrel, kak ona grohochet, krutitsya i shipit mezh kamnej, i chuvstvoval vsej kozhej, kakaya e' to ledyanaya, obzhigayushhaya voda [You walk down to Alma-Atinka, stop by the stones, stay and watch its thundering, twisting and hissing among the stones and you feel through your skin its bone-chilling and burning nature] (Yu. O. Dombrovsky); Duet veter, kachaya derev`ya, bry`zgaet dozhdyom. Muzhiki sumrachno molchat, glyadya na Egora ispodlob ya [The wind is blowing, shaking the trees and spraying the raindrops. The men keep gloomy silence, glowering Egor] (M. Gorky); S utra dozhd — to pry`skaet tumanom, to prosto l'yot [It is raining since morning either drizzling or pouring] (M. Osadchy). The quasi-blow is expressed by a vibrantum: Germ. /r/, Rus. /r/, a lack of acoustic accent is expressed by a fricative or an affricate: Germ. /s/, /t $\int /, / \mathrm{pf} /$; Rus. /z/, /s/.

The articulatory onomatopes that nominate sound processes occurring in man's nose, mouth and throat cavities (German schlapp "the sound of gulping down, lapping", mummeln "chew"), can rarely be seen among lexical units, indicating the sounds of water movement. In German and Russian languages only one verb of this type has been found so far: Germ lecken "flow, leak," (lecken "lick"), Rus. lizat' "touch something, covering, smashing (about the wave, etc.)", Germ. Kleine Wellen lecken die Ufer hinauf, spülen über harten Sand und steuern ihren Teil zu dem Wellengewirr auf der Flussoberfläche Rus. Volny` lizhut podoshvy` ego torbasov, i hochetsya shagnut navstrechu korablyu, samomu krasivomu korablyu, kotory`j kogda-libo videl Avaj [The waves lick the soles of his high fur boots and there is a desire to step towards the ship, the most beautiful ship Avaj has ever seen] (Yu Rytkhau).

Thus, the sound of water in German and Russian is expressed by 12 various types. Such a large number of models is determined, on the one hand, by the properties of the water movement, i.e. its speed, intensity, frequency, etc., on the other hand, by various phonic iconicity functions of phonemes.

Table 1 shows the data of the comparative quantitative analysis of the water onomatopes composition in German and Russian.

In German, the pure blow (instants) and dissonant sounds (frequentatives) are the least frequently used only $7.5 \%$. In the Russian language, these classes are slightly larger in number: the instants are $12.5 \%$, the frequentatives are $15 \%$. The tone sounds (continuants) are equally represented in German and Russian languages $17.5 \%$. The most numerous sounds are tone-blow sounds (instants-continuants): in German their number is $32.5 \%$, in Russian they comprise 30\% and tone-blow dissonant sounds (frequentatives quasi-instantscontinuants): in German their number is $35 \%$, in Russian language they comprise $25 \%$. The comparative analysis data of water sounding onomatopes somewhat differ from those of acoustic onomatopoeia in general [10]. Table 2 shows the data of this analysis. 
Table 1. Comparative quantitative analysis of the water onomatopes.

\begin{tabular}{|c|c|c|c|c|}
\hline \multirow{3}{*}{ Type of acoustic onomotopes } & \multicolumn{4}{|c|}{ Quantity } \\
\hline & \multicolumn{2}{|c|}{ Number } & \multicolumn{2}{|c|}{$\%$} \\
\hline & Germ & Rus & Germ & Rus \\
\hline Instants & 3 & 5 & 7,5 & 12,5 \\
\hline Continuants & 7 & 7 & 17,5 & 17,5 \\
\hline Frequantatives & 3 & 6 & 7,5 & 15 \\
\hline Instants-Continuants & 13 & 12 & 32,5 & 30 \\
\hline Frequantatives-Quasiinstants-Continuants & 14 & 10 & 35 & 25 \\
\hline Total & 40 & 40 & & \\
\hline
\end{tabular}

Table 2. Comparative quantitative analysis of acoustic onomatopoeia.

\begin{tabular}{|l|c|c|c|c|}
\hline \multirow{2}{*}{ Type of acoustic onomotopes } & \multicolumn{4}{|c|}{ Quantity of Roots } \\
\cline { 2 - 5 } & \multicolumn{2}{|c|}{ Units } & \multicolumn{2}{c|}{$\%$} \\
\cline { 2 - 5 } & Germ & Rus & Germ & Rus \\
\hline Instants & 36 & 48 & 20 & 22 \\
\hline Continuants & 20 & 26 & 11 & 12 \\
\hline Frequantatives & 38 & 64 & 21 & 28 \\
\hline Instants-Continuants & 54 & 45 & 31 & 20 \\
\hline Frequantatives-Quasiinstants-Continuants & 30 & 38 & 17 & 17 \\
\hline & 178 & 220 & & \\
\hline
\end{tabular}

Thus, the water sounds (40 units) comprise $22 \%$ of the total root number of acoustic onomatopes in German (178 units), and $18 \%$ in Russian (220 units). The water sounds in German and Russian languages are mostly complex combined sounds: tone-blow and toneblow dissonant sounds $(67,5 \%$ in German, $55 \%$ in Russian). It should be noted that the number of instant-continuants in this study practically coincides with the data on the German acoustic onomatopoeia as a whole (German - 32.5\% and 31\%), but significantly differs from those on the Russian acoustic onomatopoeia (Russian - 30\% and 20\%). The number of frequentatives quasi-instants -continuants expressing water sounds considerably exceeds the data on acoustic onomatopoeia (German: $32.5 \%$ and $17 \%$, Russian $-25 \%$ and $17 \%)$. In Russian, instants and frequentatives slightly outnumber those in German $(12,5 \%$ and $15 \%$ versus $7,5 \%$ and $7.5 \%$ ) that is significantly different from the comparative data on the acoustic onomatopoeia (instants: German - 20\%, Russian - 22\%, frequentatives: German - 21\%, Russian - 28\%).

The following universal properties of linguistic units interpreting the water sounding have been found: 1) the sounds of water take a significant place in the German and Russian phonosemantic sound picture of the world: approximately $20 \%$ in the German and Russian languages; 2) 40 verbs having a phonic iconicity origin and being essentially acoustic onomatopes have been studied so far; 3) sounding of water in German and Russian is represented by 12 types. By using S.V. Voronin`s universal phonosemantic typology seven types of sounds and five types of sound combinations have been revealed; 4) all onomatopes are structured according to the general model at the level of phonotypes; 5) there is a large number of onomatopes, where an explosive is in the anlaut position and either sonant (type 12) or vibrant (type 5, 16, 17) are in the inlaut position: Germ. brodeln, blubbern, glucksen, klatschen, gluckern, plätschern; dröhnen, trommeln, prasseln, pritscheln; Rus. klokotat` bubble, pleskat`sya "swash", gremet` "thunder", gromy`hat` "pour heavily", gryanut` "burst out", grohotat` "thunder", bry`zgat’ "splash", pry`skat` "drizzle", kropit` "sprinkle", barabanit’ "patter", tarabanit' "beat on". The correlation of semantic 
category of multiplicity (repetition) of sound and action and RL-formants (the formants with the sonants $r, 1$ ) is considered as a phonosemantic universal [22]; 6) the sound intensity is expressed by an explosive, often sonorous, and also by a vibrant or a sonant: Germ. brodeln, donnern, dröhnen; Rus. klokotat' "bubble", grohotat' "thunder", gremet' "thunder"; 7) the sound moderation is expressed by a fricative / affricate: German. Rauschen "rustle", zischen "hiss"; pritscheln "purl, swash", spritzen "sprinkle", sprühen "spray"; sprudeln "spout (about the spring)"; strömen "flow (about water) "; 8) a quiet, monotonous sound is expressed by long vowels: nieseln, pieseln "drizzle"; Rus. seyat" "drizzle", sy`pat' "pour", and by articulatory onomatops as well; Germ. lecken "flow, leak" (lecken "lick"), Rus. lizat' "touch something, embracing, smashing (about a wave, etc.)".

The following peculiarity can be attributed to the charachteristic features (idioethnicity) of water sounding: in Russian, the intensity of sound is expressed by a phonestem / hl /: hlestat` "beat down", hly`stat` "whip", hlyupat` "squelsh", hloby`stat` "guzzle", hly`nut’ "gush".

Thus, the sounds of water movement occupy a significant place in the German and Russian phonosemantic picture of the world. The phonosemantic and quantitative study of the verbs expressing water confirms the conclusion that the isomorphism features prevail over the allomorphism. The water sounds in German and Russian represent mainly a complex "composition": tone-blow (sonants and explosive) and tone-blow dissonant sounds (vibrants, sonants, a moderate sound is expressed by a fricative / affricate).

\section{References}

1. N. V. Grishina, Concept WATER in the linguistic picture of the world on the basis of nominative and metaphorical fields of the Russian language of XI - XX centuries (Saratov, 2002)

2. O. V. Gunkina, Concept "Wasser" in German artistic picture of the world in diachronic and synchronic aspects (Moscow, 2010)

3. T. I. Badmaeva, Concept "water" in English linguistic culture (Volgograd, 2006)

4. D. D. Hajrullina, Binary concepts "fire" and "water" as a fragment of linguistic picture of the world (on the material of the English and Tatar languages) (Kazan, 2009)

5. O. Yu. Arseneva, Filologicheskiye nauki - Voprosy teorii I praktiki, 4(58) (2016)

6. U. Hass, Das Konzept Wasser in der Sprache der alltäglichen und öffentlichen Diskussion (http://www.climate-service-center.de/imperia/md/content/csc/warnsignal klima/warnsignal_klima_wasser_kap1_1.4_hass5.pdf)

7. M. G. Vershinina, Explication of phonosphere in Russian phonosemantic sound picture of the world (PGU, Perm, 2013)

8. N. V. Drozhashchih, Synergetic model of iconic linguistic space (Barnaul, 2006)

9. A. B. Mihalyov, Voprosy Kognitivnoy Lingvistiki, 1 (2014)

10. O. V. Shestakova, The world in the light of onomatopoeia (Perm, 2016)

11. S. S. Shlyahova, M. G. Vershinina, Filologicheskie zametki, 1 (2014)

12. S.S. Shlyahova, A different language: the experience of marginal linguistics (2005)

13. S. S. Shlyahova, A. S. Lobanova, Sound desciptiveness in the Komi-Perm language (PGGPU, Perm, 2012)

14. Yu. V. Kazarin, The problems of phonosemantics of the poetic text (Ekaterinburg, 2000) 
15. N. A. Kurashkina, Sound denotations as representation of the sound sphere in language: on the material of English, French and Russian anthropo- and ornito-phones (Ufa, 2007).

16. S. V. Voronin, Of the semantic structure of the phonoiconic word: sense and meaning at the lexical and syntactical levels (Kaliningrad, 1986)

17. V. V. Levickij, Ehtimologicheskij slovar' germanskih yazykov: v 2-h t. [Etymological Dictionary of germanic languages in 2 vol.] Chernovtsy: Nova Kniga, T. 1, 616; T. 2, 368 (2010)

18. M. Fasmer, Etymological dictionary of the Russian language (http://dic.academic.ru /contents.nsf/vasmer).

19. P. Ya. Chernyh, Russ. Yaz., 1-2 (1999)

20. Duden, Das grosse Wörterbuch der deutschen Sprache in 10 Bänden (2012)

21. S. V. Voronin, Fundamentals of phonosemantics (LGU, Leningrad, 1982)

22. N. V. Bartko, English sound desciptive RL-verbs (2002) 